\title{
THE SYSTEMIC FAMILY ASSESSMENT SYSTEM: ITS VALIDITY WITH ASTHMATIC CHILDREN AND THEIR FAMILIES
}

\author{
Dóris Lieth Peçanha* \\ Carl Lacharité\#
}

\begin{abstract}
The construct and concurrent validity of the Systemic Family Assessment (SFA) system was tested. Participants were 11 asthmatic and 14 healthy Brazilian children (aged 5 to 9) along with their intact families. Measures included the SFA, the Family Colored Drawing Test with children (FCDT), and a semi-structured interview with parents (PI). Comparisons between families of asthmatic and healthy children yielded significant differences for all family dimensions of the SFA. The most affected dimensions for families of asthmatic children were the individuation process within the family, family conflicts, family integration and cohesion, roles, and quality of leadership within the family. Significative correlation between the SFA and the two independent measures were found. Results support the construct and concurrent validity of the SFA.
\end{abstract}

Key words: Family test, pediatric asthma, systemic assessment.

\section{AVALIAÇÃO FAMILIAR SISTÊMICA: SUA VALIDADE COM CRIANÇAS ASMÁTICAS E SUAS FAMÍLIAS}

RESUMO. Foi testada a validade de construto e a validade concorrente do protocolo de Avaliação Familiar Sistêmica (AFS). Os participantes foram crianças brasileiras, 11 com asma e 14 saudáveis (5 a 9 anos) e suas famílias intactas. Medidas incluíram o protocolo AFS, o Teste de Desenho Colorido da Família com as crianças (TDCF), e uma entrevista semiestruturada com os pais (EP). Comparações entre as famílias de crianças asmáticas e as saudáveis evidenciaram diferenças significativas em todas as dimensões familiares da AFS. As dimensões mais afetadas nas famílias de crianças asmáticas foram o processo de individuação familiar, conflitos, integração familiar e coesão, papéis, e qualidade da liderança dentro da família. Foi encontrada uma correlação significativa entre a AFS e as duas medidas independentes. Os resultados apóiam a validade de construto e a validade concorrente da AFS.

Palavras-chave: teste da família, asma pediátrica, avaliação sistêmica.

\section{EVALUACIÓN FAMILIAR SISTÉMICA: SU VALIDEZ CON NIÑOS ASMÁTICOS Y SUS FAMILIAS}

RESUMEN. La validez de constructo y la validad coexistente do protocolo de Evaluación Familiar Sistémica (EFS) fue establecida. El estudio fue realizado en Brasil con familias intactas, y observó 11 niños con asma y 14 saludables, con edades de 5 a 9 años. Las medidas analizadas incluyeron el EFS, el Test del Dibujo Coloreado de la Familia aplicado a los niños (TDCF), y una entrevista semi-estructurada aplicada a los padres (EP). Las comparaciones entre las familias de niños asmáticos y saludables apuntaron diferencias significativas en todas las dimensiones familiares de la EFS. En las familias de niños asmáticos las dimensiones más afectadas fueron el proceso de la individuación dentro de la familia, los conflictos familiares, la integración familiar y la cohesión, los papeles y la calidad de liderazgo dentro de la familia. Se encontró una correlación significativa entre el EFS y las dos medidas independientes. Los resultados prueban la validez del constructo y la validad coexistente del EFS.

Palabras-clave: test de la familia, asma pediátrica, evaluación sistémica.

* PhD. Associate Professor, Department of Psychology, Universidade Federal de São Carlos, São Paulo, Brazil.

\# PhD. Full Professor, Department of Psychology, Université du Québec à Trois-Rivières, Québec, Canadá. 
This study was designed to test the construct and concurrent validity of a coding system for family assessment, called the Systemic Family Assessment (SFA) instrument. When examining the validity of an investigation, several aspects, such as the theoretical validity, the internal and external validity, and the validity of the statistical conclusions, are taken into account. Relevant aspects of the systemic theory and of the variables selected to assess family functioning are thus made clear.

Systemic thought is defined by a circular character - as opposed to linear - and by a holistic approach - as opposed to an individual approach. It views each member of a family as having an influence over the other, as in a circular chain reaction (Bateson, 1979; Jackson, 1981). This convergence of interactions has a synergetic character, in other words, it produces a new quality that may be identified as the occurrence of a psychosomatic symptom in one of the family members. For purposes of this study, we are concerned with psychosomatic families (Minuchin, Rosman \& Baker, 1978). In spite of the criticism surrounding the use of this term (Peçanha, PérezRamos \& Lacharité, 2003), it has steadily been used to designate those families having one member suffering from a psychosomatic illness - or rather, a somatic illness in which emotional or psychological factors play an important role. Asthma is a classic example of a psychosomatic illness (Alexander, 1950/1989; Sperling, 1949). Although consensus has emerged from the clinical, social, psychological, and biological sciences literature that psychosocial factors affect asthma morbidity in children (Klinnert, Price, Liu \& Robinson, 2003), their role in the genesis, incidence, and symptomatology of asthma remains controversial since mechanisms are not well understood (Wright, Rodriguez \& Cohen, 1998). These authors conclude that causality is at least bidirectional or reciprocal and most probably cyclic in complexity, supporting the systemic approach in the study of asthma.

Systemic investigations (Gustafsson, 1987; Liebman, Minuchin, Baker \& Rosman, 1976; Minuchin et al., 1975; Onnis, 1989, 1994; Peçanha, 1997) suggest that the existence of a chronic illness is not sufficient to negatively affect patterns of interaction and family transactions. Some of these studies (Gustafsson, 1987; Onnis, 1989, 1994; Peçanha, 1997) reveal the existence of transactional patterns that are typically repetitive and severely dysfunctional among families, confirming the psychosomatic characteristics described by Minuchin, Rosman and Baker (1978). They are: 1) enmeshment; 2) over-protectiveness; 3 ) rigidity; 4) and absence of conflict resolution.
Dysfunctional transactions in families with an asthmatic child, particularly conflict denial, difficulty in expressing feelings of hostility, and generation gap confusion are topics described in several writings (Onnis, 1989; 1994; Peçanha \& Pérez-Ramos, 1999; Peçanha et al., 2003). Worth mentioning is the part that asthma plays in avoiding roles definition in the subsystems (marital, parental, fraternal, and filial) that make up the family system, particularly in the marital subsystem. In some instances, family leadership appears to be exercised in a masked form by a child who will take on a role beyond her or his competency. This situation frequently involves triangulation (Fivaz-Depeursinge \& Favez, 2006) between parents and sick child, alliances, coalitions, or conflict evasion through messages exchanged through this child. Thus, asthma can be an indication of a fragile and rigid family balance. This illness seems to contribute towards blocking the individuation process (Onnis, 1994; Peçanha, 1993; Peçanha, 1997; Peçanha \& Piccinini, 1994) within the family system, placing on the child the weight of the symptoms, and creating in the family a diffuse feeling of uneasiness, poor affective expression, and non-gratifying levels of integration.

The evidence that has been described about dysfunctional families with asthmatic children points to the external validity, or known-validity, regarding this population even though the distinctness of each case is identified. As for the internal validity of a research, it can be threatened by different factors such as participants' selection.

Asthma is a multifactor illness displaying an interaction of complex physiological, psychological, social, and environmental factors. Therefore, the existence of a control group with allergy problems could pose a threat to the internal validity of an investigation involving asthmatics. Frequently, relief attained through the use of medication in a period of crisis that is not followed by a readjustment in the child's psychosomatic family balance favors the appearance of dermatitis in children (Stevenson, 2003), or causes asthma to alternate with other allergic symptoms. There are other factors concerning participants that may threaten the validity of studies about asthma in children such as: too wide age brackets, differences in human development contexts, diverse family life cycle, and lastly, the comparison of severe asthmatics to healthy children.

\section{THE SYSTEMIC PERSPECTIVE ON FAMILY ASSESSMENT METHODS}

Assessment methods have fallen into two main categories (Peçanha et al., 2003). The first one is comprised of methods based on the evaluation of 
family members' individual answers, while the second is based on the evaluation of group answers. The methods in the first category include some projective tests and several questionnaires. Among the projective tests, the family drawing test is the most popular. This individual test was the target of a systemic evaluation made by the first author examining the validity of family functioning dimensions such as: communication, rules, roles, conflicts, and aggressiveness.

Over the last 40 years, there have been many studies designed to examine the reliability and validity of assessments based on drawings. In terms of the presence or absence of objective features, the reliability of drawing tests could be acceptable (Thomas \& Jolley, 1998). The researchers examined the complexity of factors involved in the drawing test, and upon evaluation of personal significance of topic depicted, as it happens in the family drawing test, they concluded in favor of its validity. As a result of a controlled study about this issue, the researchers made some recommendations to enhance drawing reliability and validity. They include using clinical samples, collecting and comparing drawings from control children to assist in the interpretation of drawings with affectively characterized topics, not basing drawing interpretation solely on the finished drawing, and incorporating other relevant information, procedures and sequences used in making the drawing. These recommendations were followed when the family colored drawing test (Maggi, 1970) was administered to cancer children (Peçanha \& Fernandes, 2003), asthmatics, and a control group of healthy children (Peçanha, 1997).

In methods of group observation, the family is viewed as a group and is examined by means of its transactions. However, it is essential to ensure that the techniques utilized, mostly structured family task interviews, allow for a precise evaluation of the variables involved in family functioning (FéresCarneiro, 1983; Peçanha et al., 2003).

Among the structured interviews that enable the family to be assessed as a group, the structured family interview (SFI - Féres-Carneiro, 1983) presents the following advantages: 1 . an average duration of 40 minutes; 2. various families are eligible to participate - there are no requirements as far as family structure, education, age or competency; 3. it encourages spontaneity in the family since tasks are clear, nonintrusive, and some are hypothetical; 4. it is quietly audio-recorded, and the observer is outside the family's field of observation. The advantages of video-recording when examining human interactions are known; however, the intrusive character of this device can threaten the validity of the study (Tribblee et al., 2003). Moreover, the SFI provides for the evaluation of essential dimensions in the family diagnosis, as per review of the writings on the subject (Carr, 2000; Peçanha et al., 2003).

\section{RESEARCH GOAL AND HYPOTHESES}

This study aims at testing the construct and concurrent validity of the Systemic Family Assessment system (SFA). We predict positive relations among the indicators of family functionality obtained through the SFA and those obtained by focusing on individual information that children (Family Colored Drawing Test - FCDT) and parents have about their own families (Parental Interview - PI). We also predict that families of asthmatic children exhibit greater dysfunctional patterns on the three clinical measures as compared to families of healthy/normal children.

\section{METHOD}

\section{Participants}

To ensure the validity of the study, the choice of participants was based on the mixed group design. On the one hand, the utilization of a mixed sample allowed for the variance increase inside the indicators retained; on the other, it enabled the testing of the hypothesis about the differences between the contrasted groups (known-group validity).

Participants were 25 children with their respective two-parent intact families: 11 are asthmatic and 14 are healthy (mean age $=7.77$ years, $S D=.87 ; 68 \%$ are boys). The diagnosis of light asthma, made by the child's doctor, took into account the characteristics of the crisis, its annual frequency, and the medical care required. The following criteria were utilized in selecting the asthmatic group: children aged 5 to 9 with a mental, physical and psychological healthy development, no record of interfering illnesses, having permanently resided with the biological family; mothers with college or university education; nuclear and intact families, with no history of psychiatric treatment, separations or bereavement in the nuclear family, with access to education and medical services; presence of only one asthmatic child among other healthy children. These criteria aimed at acquiring a more advanced knowledge of family functioning in the presence of asthma, preventing it from being masked by other variables. 
In order to form a comparison group, families were selected along the same criteria, except for the occurrence of asthma. The healthy children met the conditions of not having a history of bronchial illnesses, or of any other disease of allergic nature, which would threaten the research's internal validity. The mothers' level of education (college or university) was carefully monitored. Mothers whose levels of education are lower than college generally come from a poor socio-economical background where the family's lack of financial resources can adversely impact children's health and education (Klinnert et al., 2001). The two groups are equivalent regarding age, gender, and family rank of the target children, mothers' and fathers' age, educational, and occupational level, and number of children at home.

\section{Measures}

Structured Family Interview and Systemic Family Assessment System. The Structured Family Interview (SFI) is a structured interview comprised of six tasks which are assigned to the family as a group (FéresCarneiro, 1983), and its purpose is to evaluate the family' structure and functionality. The transactional processes are observed first-hand by the interviewer and by a trained observer who audio-records and documents the non-verbal signals. In this study, the SFI results are assessed by means of the coding system called the Systemic Family Assessment (SFA) system. The FSA was inspired by Féres-Carneiro's model of family assessment. Adaptations and more detailed descriptions of the model are found in previous publications (Peçanha \& Pérez-Ramos, 1999; Peçanha et al., 2003). The SFA includes nine rating scales and an operational coding system for each one of them. The five-point Likert-type scale aims at assessing nine transactional dimensions: communication, rules, roles, leadership, conflicts, aggressiveness, affectivity, individuation and integration. Each dimension is evaluated by items stretched over a continuum where 1 is very dysfunctional, 2 is dysfunctional, 3 is borderline functionality, 4 is functional, and 5 is very functional. The score for each dimension is derived from the average score obtained from the four variables that comprise it. The operational coding system involves the operational definition of each dimension as well as the operational definition of each item that comprises that dimension.

Parental Interview. A semi-structured interview was conducted with the child's parents in order to gather information about the child's development and family functioning. In conducting the assessment, the qualitative research criteria were applied. From the exam of the parental verbal descriptions, a number of categories to study were raised. At first, those that concerned the parental subsystems' functions such as "limits and educational concessions granted to the child" were analyzed. The evidence presented in writings that children with a chronic disease, especially those that have asthma, tend to be overprotected by parents (Castro \& Piccinini, 2002; Peçanha \& Pérez-Ramos, 1999) was taken into account. Initially, the limits set to children's behavior and who was responsible for setting them was evaluated. Also assessed was the existence of a family "routine". The answers to these categories were dichotomously scored ( $0=$ dysfunctional; 1 = functional $)$, with the exception of "limits setting" that was assessed on three levels $(0=$ dysfunctional; $1=$ limits set only by the mother; 2 = limits set by both parents). In what concerns "educational concessions granted to the child", two categories were obtained: "sleep with parents" and "frequently be showered with gifts" (apart from dates of significant events). The act of showering the sick child with presents has been associated with feelings of parental guilt (Peçanha, 2001). The assessment was also performed on two levels: presence or absence of these behaviors. Another area for analysis were the transactions which were equally scored in a dichotomous manner $(0=$ dysfunctional; 1 = functional). Here we have the parental subsystem with the categories "quality of transaction between child and parents" and "parental agreements over educational rules"; the marital subsystem with the category "time for the couple"; and the family system as a whole with the category "social activities engaged in by the entire family".

Family Colored Drawing Test. The Family Colored Drawing Test (FCDT) was conceived by Maggi (1970) as an improvement over the projective graph technique called Desenho da Familia (Corman, 1970). The FCDT exhibits greater standardization in its application when compared to other family drawing tests (Jourdan-Ionescu \& Lachance, 1997). The material utilized is as follows: a blank sheet of paper 8 by 11 in.; 10 sharpened colored pencils arranged from left to right, in the following order: white no. 001; red no. 021; orange no. 009; yellow no. 007; brown no. 077; green no. 070; blue no. 043; purple no. 034; gray no. 097; black no. 099 (the numbering refers to the Johann Faber brand; if not available, it is recommended to use primary colors and to avoid selecting light and dark tones); a sharpener; a black pencil no. 2; a white or colorless eraser; a chronometer to measure the reaction time of the child and the amount of time he or she took to complete the test. The instructions provided were: "Do a colored drawing of a family in any 
way you wish, in the best way you can, using the pencils available". The way these instructions were laid out (Corman, 1970; Maggi, 1970) took into account the evidence that direct stimuli tend to block the free expression of the subject. Moreover, Morval (cited by Jourdan-Ionescu \& Lachance, 1977) indicated that children aged 8 and younger tended to draw their own family, therefore, making it unnecessary to explicitly ask them to do it. Peçanha (1997) developed an adaptation of the FCDT with a view to greater standardization and efficiency in data gathering and analysis. The adapted version of the FCDT was chosen (Peçanha, 1997) because it enables the study of the family group dimensions according to the child representation, and it also enables the comparison between this set of data and the one obtained through the Systemic Family Assessment (SFA) instrument in reference to the same dimensions: communication, rules, roles, conflicts, and aggressiveness.

In assessing the family drawing, the age of the child was taken into account and the choice of colors provided additional elements (Burkitt, Barrett \& Davis, 2003). The answers provided in the questionnaire were essential for scoring each variable according to the systemic protocol developed by the first author of this research. And the graphic aspect acted as a backup confirming (or not) the child's verbal description. Dichotomous variables were used ( 0 = dysfunctional; 1 = functional) to assess the test, with the exception of the "rules" dimension, which was assessed on 3 levels $(0=$ omitted rules; $1=$ authoritarian rules; 2 = functional).

\section{Procedures}

Asthmatic children were recruited through pneumology services in community health centers. This facilitated the comparison between the groups, contrary to the majority of studies carried out in hospitals and allergy clinics that take in gravely ill patients. The children in the comparison group were recruited through schools in the same region as the health centers, in a growing city in the state of São Paulo, Brazil. The purpose was to recruit families living in as similar social, cultural, and economical conditions as possible.

Parents were asked to sign a "Terms of Informed Consent" form as a condition for voluntary family participation in the research. One of the researchers introduced herself to the families as a psychologist who was conducting a research about child development and family functioning. She explained the need for holding two sessions at the family's home, and clarified that the activities would unfold in the following order: 1) Interview with parents; 2) Family Colored Drawing Test administered to child; 3) Structured Family Interview, jointly conducted with all members of the nuclear family.

The child was free to comment (or not) on his or her drawing and to answer (or not) the questions related to it. It is important to bear in mind that the child was asked to do a drawing of $a$ family, and not to do a drawing of his or her family, as a way of safeguarding her or his privacy and establishing the distance that is necessary in projective situations. In the structured family interview, participants were given ample freedom to respond in their own way to the tasks assigned to them.

The interviews with parents and the entire family as well as the family drawing test were audio-recorded and transcribed word-for-word for later analysis. The comments were added to the final transcript (nonverbal signals, emotional expressions etc.). Two independent clinic psychologists with special training were in charge of codifying the three instruments. The children's state of health was omitted in the assessment protocol.

\section{RESULTS}

Non-parametric statistics have been used for all analyses. Co-relational analyses have been used to examine the construct and concurrent validity of the Systemic Family Assessment (SFA) instrument in relation to indicators of functionality drawn from parental perceptions of some aspects of the family life (Parental Interview - PI) and target children's perceptions in reference to some aspects of their family functioning (Family Colored Drawing Test FCDT). The SFA known-group validity has been assessed through comparisons between families of asthmatic children and families of healthy children.

\section{Construct and concurrent validity}

The first result that is noteworthy is the proportion of significant correlations: $63 \%(95 / 150)$ presented by Spearman's correlation coefficients (rank order correlations) between SFA and other measures for the entire sample. This result suggests the presence of a large covariance effect between the SFA and indicators of family functioning based on children's perceptions (FCDT) and those of parents (PI). Correlations between total scores showed a similar phenomenon: $.60(p<.01)$ between SFA and FCDT total scores, and $.72(p<.001)$ between SFA and PI total scores. 
The co-relational matrix (Table 1) also shows complex relations between nine SFA components and five FCDT components for the target children. Four out of five FCDT dimensions are significantly correlated with matching SFA dimensions (rules, roles, conflicts, and aggressiveness). "Communication" in both measures does not seem to converge, although children's representations of family communication are positively associated with five SFA dimensions as well as with SFA global score. Furthermore, target children's perceptions of the functional application of family rules, and functional management of aggressiveness are positively associated with every SFA dimension. "Conflicts" as perceived by children are positively associated with seven SFA dimensions. In the same way, "roles" as perceived by children are associated with four SFA dimensions. Thus, as soon as any dimension of the family dynamics shows signs of dysfunction (in the SFA), children will represent their families as having more difficulties in what concerns the quality of family rules (explicitness, coherence, flexibility), coping strategies in family conflict (recognition and conflict resolution) and expressing hostility (positive expression, recognition, and acceptance of hostile feelings).

Table 1. Rank Order Correlations Between Scales on the Systemic Family Assessment (SFA) Instrument and Indicators of Family Functioning Based on Family Colored Drawing Test (FCDT) by the Children.

\begin{tabular}{|c|c|c|c|c|c|c|}
\hline \multirow[b]{2}{*}{ SFA } & \multicolumn{6}{|c|}{ FCDT } \\
\hline & Total & $\operatorname{Com}^{b}$ & Rul & Rol & Con & Agg \\
\hline Total & $.60 * * *$ & $.43^{*}$ & $.62 * * *$ & & $.50 * *$ & $.53 * *$ \\
\hline Communication & $.46^{*}$ & & $.57 * *$ & $.41^{*}$ & $.48^{*}$ & $.53^{* *}$ \\
\hline Rules & $.45^{*}$ & & $.43^{*}$ & & $.52 * *$ & $.41 *$ \\
\hline Roles & $.56^{* *}$ & $.57 * *$ & $.46^{*}$ & $.50 * *$ & $.40^{*}$ & $.49^{* *}$ \\
\hline Leadership & $.53 * *$ & & $.51^{*}$ & $.39 *$ & $.47 *$ & $.46^{*}$ \\
\hline Conflict & $.51 * *$ & $.41 *$ & $.57 * *$ & & $.46^{*}$ & $.48 * *$ \\
\hline Aggression & $.42 *$ & & $.60 * * *$ & & & $.44^{*}$ \\
\hline Affection & $.60 * * *$ & $.40^{*}$ & $.47^{*}$ & $.47 *$ & $.47 *$ & $.53^{* *}$ \\
\hline Individuation & $.46^{*}$ & $.49 * *$ & $.67 * * *$ & & & $.62 * * *$ \\
\hline Integration & $.62 * * *$ & $.45^{*}$ & $.55^{* * *}$ & & $.62 * * *$ & $.53 * *$ \\
\hline
\end{tabular}

Com $=$ Communication $;$ Rul $=$ Rules $;$ Rol $=$ Roles $;$ Con = Conflict $;$ Agg = Aggression . Non-significant correlations have been omitted. $p<.05 * * p<.01 * * * p<.001$

The relations between the SFA and family functioning parental reports are also highly significant (Table 2). In particular, the involvement of both parents in setting limits and responsibilities to children is associated with every SFA dimension. The presence of clear family routines is associated with eight SFA dimensions, and the parental agreement over educational values for children is associated with seven SFA dimensions. Thus, as soon as a dimension of the family dynamics shows signs of dysfunction (in the SFA), parents will represent their families as having more difficulties in what concerns the functioning of the parental and the parent-child subsystems.

Table 2. Rank Order Correlations between Scales on the Systemic Family Assessment (SFA) Instrument and Indicators of Family Functioning Based on Parental Interview (PI).

\begin{tabular}{|c|c|c|c|c|c|c|c|c|c|}
\hline \multirow[b]{2}{*}{ SFA } & \multicolumn{9}{|c|}{ PI } \\
\hline & Total & $\operatorname{Lim}^{\mathrm{b}}$ & Rou & Sleep & Gifts & C-P & T-Cou & Soc & Edu \\
\hline Total & $.72 * * *$ & $.85 * * *$ & $.54 * *$ & $.46^{*}$ & ,39* & & & & $.54 * *$ \\
\hline Communication & $.55^{* *}$ & $.62 * * *$ & $.58 * *$ & $.52 * *$ & $.40^{*}$ & & & & \\
\hline Rules & $.54 * *$ & $.65^{* * *}$ & $.57 * *$ & & & & & & $.41 *$ \\
\hline Roles & $.74 * * *$ & $.78 * * *$ & $.52 * *$ & & & $.45^{*}$ & & $.39 *$ & $.59 * *$ \\
\hline Leadership & $.74 * * *$ & $.79 * * *$ & $.62 * * *$ & & & $.55^{* *}$ & & & $.54 * *$ \\
\hline Conflict & $.68^{* * *}$ & $.86^{* * *}$ & $.57 * *$ & & & & & & $.57 * *$ \\
\hline Aggresion & $.44 *$ & $.62 * * *$ & & & & & & & $.40 *$ \\
\hline Affection & $.63^{* * *}$ & $.56^{* * *}$ & $.44^{*}$ & $.45^{*}$ & & & $.55^{* *}$ & & \\
\hline Individuation & $.60 * * *$ & $.73 * * *$ & $.55^{* *}$ & & & & & & $.61 * * *$ \\
\hline Integration & $.64 * * *$ &, $81^{* * *}$ & $.39 *$ & $.42 *$ & & & & $.41^{*}$ & $.53 * *$ \\
\hline
\end{tabular}




\section{Known-group validity}

Figure 1 shows comparisons of various family functioning indicators between families of asthmatic children and families of healthy children. The results of Mann-Whitney tests comparing both groups show that all scores are significant at $p<.05$. As predicted, families of asthmatic children exhibit different degrees of dysfunction ranging from mild to moderate based on the three clinical measures: SFA, FCDT, and PI. In particular, the individuation process within the family, family conflicts, family integration or cohesion, and roles and quality of leadership within the family are the most affected SFA dimensions $(p<.001)$ for families of asthmatic children.

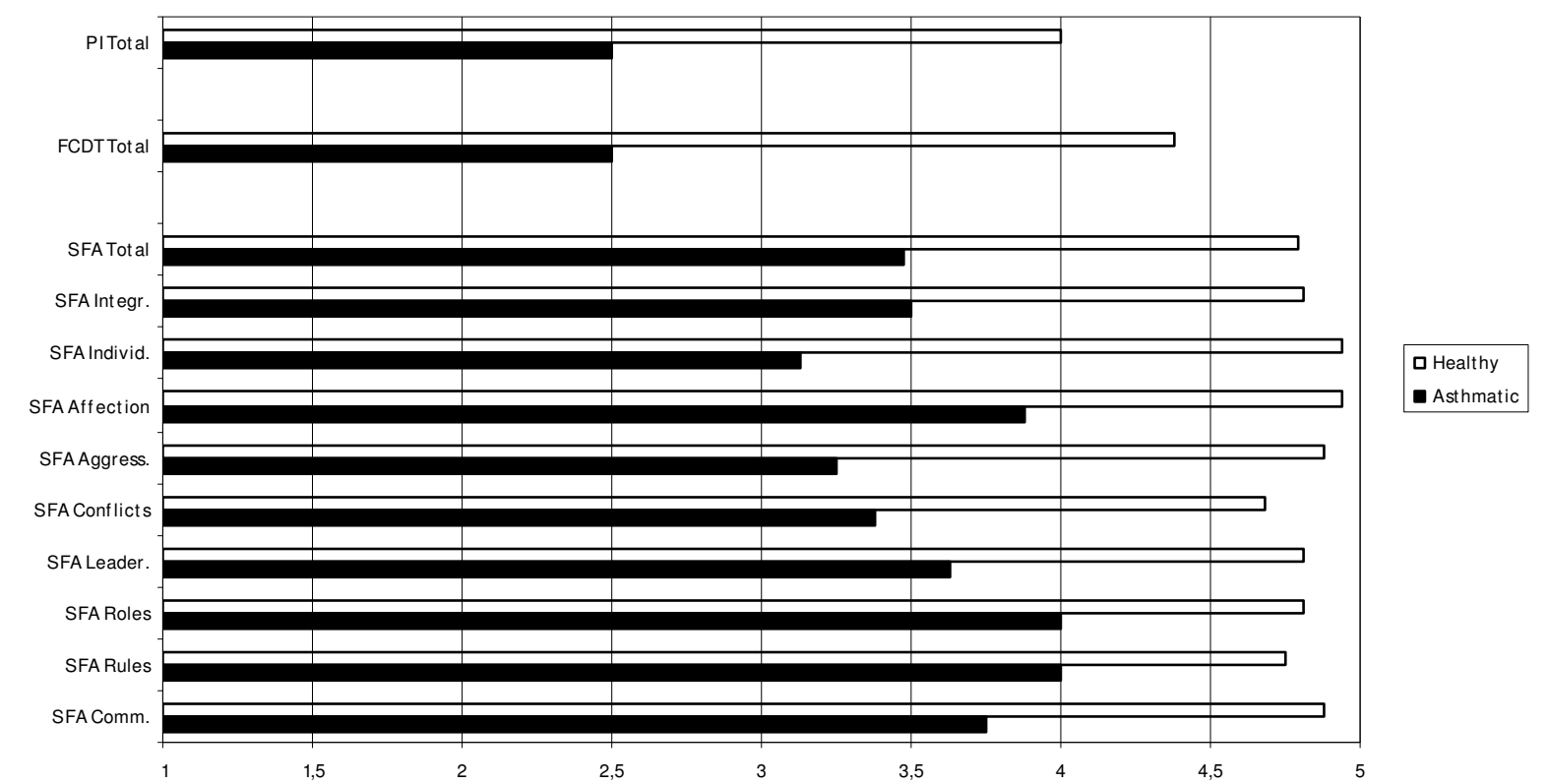

Family Assessment (SFA) Instrument, the Family Colored Drawing Test (FCDT), and the Parent Interview (PI) (All differences are significant at $p<.05)$.

Figure 1. Comparisons Between Families of Asthmatic Children and Families of Healthy Children on the Systemic

\section{DISCUSSION}

The goal of this study was to examine the validity of the Systemic Family Assessment (SFA) instrument. Two tests were carried out. The first predicted positive relations between indicators of family functionality obtained through the SFA and those obtained through individual information provided by children and parents about their own families. This procedure put to test the concurrent (links between two or more indicators of the same phenomenon) and construct (links between two or more phenomena, and their indicators, as predicted by theory) validity of the SFA. For instance, the hypothesis that the SFA dimensions would correlate with the same dimensions obtained through the Family Colored Drawing Test concerned the concurrent validity. The hypothesis that the presence of shared responsibility (among mothers and fathers) in setting limits to their children, the presence of clear family routines, and the presence of shared educational values as described by the parents would correlate with several SFA dimensions concerned the construct validity. The second test predicted differences between two groups of families known in the scientific and clinical literature to be different. In this case, families of asthmatic children and families of healthy/normal children were compared. Our own work (Peçanha et al., 2003) and the work of several other researchers (Minuchin, Rosman \& Baker,1978; Onnis, 1989) have shown that families of asthmatic children are less functional, especially in what concerns family integration, conflict resolution and hostility management when compared to families of healthy/normal children. This test constitutes a special form of construct validation of a measure known as known-group validation.

The results of this study entirely support the validity (construct, concurrent and know-group) of the Systemic Family Assessment instrument. The SFA dimensions are correlated with most of the matching FCDT dimensions for the target children. These dimensions are also correlated with several indicators of subsystem functioning obtained through the parent's interview. The results equally show that SFA 
scores significantly discriminate between families of asthmatic children and families of healthy/normal children. However, several points are noteworthy here.

First, even if several SFA dimensions are significantly correlated with equivalent FCDT dimensions, they are not specifically correlated. FCDT dimensions such as "rules" and "aggressiveness" are correlated with all SFA dimensions. SFA dimensions, such as "roles" and "affection", are correlated with all FCDT dimensions. Furthermore, except for "roles", when significant correlations are found between matching dimensions, they are not the highest among the set of possible correlations. For instance, the FCDT "aggressiveness" dimension is most highly correlated with the SFA "family individuation" dimension. The SFA "roles" dimension is most highly correlated with the FCDT "communication" dimension. These results suggest on the one hand that some of the aspects of children's internal representations of their families are more related to external transactional descriptions of family processes. Children's internal models of coherence, explicitness and flexibility of family rules, as well as their internal models of the meaning and management of hostile feelings and aggressive behaviors, seem to be good indicators of family functioning. On the other hand, external descriptions of the ways in which affection is spontaneously expressed and accepted in the family, and external descriptions of the clarity, differentiation, flexibility and adequacy of family roles seem to be good indicators of the quality of children's internalized representation of their own family.

Second, the child's representation of communicational processes within his or her family, on the one hand, is uncorrelated with the matching SFA dimension. It is rather correlated with the SFA "roles, conflicts, affection, individuation, and integration" dimensions. On the other hand, the external description of the quality of communicational processes within the family is correlated with all other dimensions of the child's internal representation of her or his family. On the surface, this suggests that the phenomenon of family communication takes on a different meaning when it is perceived or felt by the child as when it is observed and assessed by an external witness. On a deeper level, this also suggests that communication itself may not be what is most important but rather the effects of communication (observed or felt) on other aspects of family functioning.

Third, the same considerations should be applied to the observed links between the SFA and the parental report. Some aspects of the parental subsystem such as the sharing of responsibility in setting limits to children, the importance of the establishment of family routines, and the sharing of educational values seem to be good predictors of family functioning as assessed by the SFA. Thus, this study shows the merits and benefits of a multi-axial perspective on family functioning assessment. External judgments, such as those indicated by the SFA, and internal representations of the family, such as those obtained through the parental interviews and children's drawings of their families, are significantly convergent. The strength of this convergence indicates that family processes are coherently organized at the levels of intra-psychic and transactional manifestations. Results also show that this convergence between external judgments and internal representations of the family is not perfect in magnitude or specificity. This suggests that information obtained in one level could be used to "punctuate" information on other levels. For instance, in a family with an asthmatic child, when "roles" are assessed by a clinician as being rigid and/or undifferentiated, but the child in his or her drawings indicates that the family roles are functional from her or his perspective, this discrepancy should not necessarily be used to question the accuracy of the information obtained (for example, was the family stressed out by the family interview procedures?) but rather to investigate the presence of specific family processes such as the child's high sensitivity towards his or her family aspired ideal of harmony (expressed by the child in her or his family drawing).

Fourth, apart from demonstrating the SFA knowngroup validity, the comparison of families of asthmatic children with families of healthy/normal children shows the complex relationship that exists between family processes and the socio-emotional development of children.

The results of this study fully support the systemic perspective of individual and family functioning. Such perspective takes into account the interdependency between child's development, his or her symptoms (asthma) and family processes. Our results provide clear empirical evidence of these interconnections. A systemic perspective also suggests that psychosomatic symptoms are functionally linked to some transactional difficulties in the family system in which the child lives. In this sense, asthma seems to help the individual and the family system strike a psychosomatic balance. In fact, our results point to a circular process in which the symptom (asthma) is simultaneously the outcome of the individual's adaptive strategy and the family's coping strategy. Our 
results also suggest that some degree of convergence exists among families of asthmatic children. We must warn readers against turning highly complex processes into a rigid set of definitions. These convergences should be understood as clinical hypotheses waiting to be adapted to each individual child and to his or her family, and not as a stiff set of formulas to be forced upon each clinical situation.

Although for a short while relationships can be analyzed at any given point in time, there is no way of separating cause and effect. Thus, poor adjustment of the chronically ill asthmatic child may be a function of family dysfunction (high conflict, etc.), or family dysfunction may be a function of this chronic illness. Most likely, the two are not outcome measures that can be separated, but are rather interactive processes that rely not only on multiple intervening factors, but also on the appropriate timing of its process measurement to be properly assessed. In "systemic words", this study argues that causality in human systems is circular, and that no part of this system can have unilateral effect over the other.

\section{REFERÊNCIAS}

Alexander, F. (1989). Medicina psicossomática - princípios e aplicaçöes. Porto Alegre: Artes Médicas. (Original publicado em 1950).

Bateson, G. (1979). Mind and nature: A necessary unity. New York: E. P. Dutton.

Burkitt, E., Barrett, M. \& Davis, A. (2003). Children's colour choices for completing drawings of affectively characterised topics. Journal of Child Psychology and Psychiatry and Allied Disciplines, 44(3), 445-455.

Carr, A. (2000). Editorial: Empirical approaches to family assessment. Journal of Family Therapy, 22(2), 121-127.

Castro, E. K. \& Piccinini, C. A. (2002). Implicações da doença orgânica crônica na infância para as relações familiares: algumas questões teóricas. Psicologia Reflexão e Crítica, 15(3), 625-635.

Corman, L. (1970). Le test du dessin de la famille. Paris: PUF.

Féres-Carneiro, T. (1983). Família: diagnóstico e terapia. Rio de Janeiro: Zahar.

Fivaz-Depeursinge, E. \& Favez, N. (2006). Exploring Triangulation in Infancy: Two Contrasted Cases. Family Process, 45(1), 318.

Gustafsson, P. A. (1987). Family interaction and family therapy in childhood psychosomatic: A family systems approach to illness. Sweden: Linkoping University Medical Dissertation.

Jackson, D. D. (1981). La question de l'homéostasie familial. In Y. Winkin (Ed.), La nouvelle communication (pp. 224-237). Paris: Seuil.

Jourdan-Ionescu, C. \& Lachance, J. (1997). Le dessin de la famille. Paris: EAP.
Klinnert, M. D., Nelson, H. S., Price, M. R., Adinoff, A. D., Leung, D. Y. M. \& Mrazek, D. A. (2001). Onset and persistence of childhood asthma: Predictors from infancy. Pediatrics, 108(4). Retrieved December 18, 2003, from http://pediatrics. aappublications.org.

Klinnert, M. D., Price, M. R., Liu A. H. \& Robinson, J. L. (2003). Morbidity patterns among low-income wheezing infants. Pediatrics, 112(1), 49-57.

Liebman, R., Minuchin, S., Baker, L. \& Rosman, B. (1976). The role of the family in the treatment of chronic asthma. In P. J. Guerin (Ed.), Family therapy, theory and practice. New York: Gardner.

Maggi, A. (1970). Teste do desenho em cores da família. Dissertação de Mestrado Não-Publicada. Programa de Pósgraduação em Psicologia Clínica, Instituto de Psicologia, Universidade de São Paulo. São Paulo.

Minuchin, S., Baker, L., Rosman, B., Lieberman, R., Milman, L. \& Todd, T. C. (1975). A conceptual model of psychosomatic illness in children: Family organization and family therapy. Archives of General Psychiatry, 32(8), 1031-1038.

Minuchin, S., Rosman, B. L. \& Baker, L. (1978). Psychosomatic families: Anorexia nervosa in context. Cambridge: Harvard University.

Onnis, L. (1989). Corps et contexte: Thérapie familiale des troubles psychosomatiques. Paris: ESF.

Onnis, L. (1994). Sculpting present and future: A systemic intervention model applied to psychosomatic families. Family Process, 33(3), 341-355.

Peçanha, D. L. \& Piccinini, C. A. (1994). Interação mãe-criança em díades com crianças asmáticas-considerações teóricas. Arquivos Brasileiros de Psicologia, 46(1/2), 63-83.

Peçanha, D. L. (1993). A interação triádica: mãe, criança e pessoa estranha, na presença de asma infantil. Boletim de Psicologia da Sociedade de Psicologia de São Paulo, XLIII (98/99), 4758.

Peçanha, D. L. (1997). A reciprocidade de desenvolvimento entre a criança com asma e sua família. Tese de Doutorado NãoPublicada. Programa de Pós-graduação em Psicologia Clínica, Universidade de São Paulo, São Paulo.

Peçanha, D. L. (2001). Variáveis sócio-afetivas no desenvolvimento da criança com câncer em relação transacional com variáveis do sistema familiar. Boletim Academia de Psicologia, XXI(4/01), $19-21$.

Peçanha, D. L. \& Fernandes, J. V. S. (2003). O desenvolvimento da Criança com Câncer e o Funcionamento Psicológico de sua família. [Resumo]. Em Sociedade Brasileira de Psicologia (Org.), Resumos de comunicações científicas. XXXIII Reunião Anual de Psicologia. Belo Horizonte: SBP.

Peçanha, D. L. \& Pérez-Ramos, A. M. Q. (1999). Diagnóstico sistêmico da família: novas contribuições. Boletim de Psicologia da Sociedade de Psicologia de São Paulo, XLIX(110), 17-37.

Peçanha, D. L., Pérez-Ramos, A. M. Q. \& Lacharité, C. (2003) Une méthode systémique d'évaluation du fonctionnement familial: Étude portant sur les familles des enfants asthmatiques. Revue Québécoise de Psychologie, 24(2), 89-112.

Sperling, M. (1949). The role of the mothers in psychosomatic disorders in children. Psychosomatic Medicine, 11(6), 377-385. 
Stevenson, J. (2003). Relationship between behavior and asthma in children with atopic dermatitis. Psychosomatic Medicine, 65(6), 971-975.

Thomas, G. V. \& Jolley, R. P. (1998). Drawing conclusions: A reexamination of empirical and conceptual bases for psychological evaluation of children from their drawings. British Journal of Clinical Psychology, 37(2), 127-139.

Tribble, D. S., Blanchard, R., Mercier, K., Lacharité, C. Peçanha, D. L., Morin, P., Doré, C., Marchand, C. \& Archambault, J. (2003). L'approche systémique familiale: Description d'un processus de partenariat entre gestionnaires, chercheurs et cliniciens en intervention de première ligne. [Abstract]. En
Societé Quebecoise de Recherche en Psychologie (Org.), Septième symposium québécois de recherche sur la famílle ( $\mathrm{p}$. 61), Quebec, Canada.

Wright, R. J., Rodriguez, M. \& Cohen, S. (1998). Review of psychosocial stress and asthma: An integrated biopsychosocial approach. Thorax, 53. Retrieved December 18, 2003, from http://thorax.bmjjournals.com/cgi/content/full/53/12/1066.

Recebido em 09/05/2006

Aceito em 09/03/2007

Endereço para correspondência: Dóris Lieth Peçanha, Department of Psychology, Laboratório VIDA, Universidade Federal de São Carlos, Rodovia Washington Luiz, Km 235, CP: 676, CEP 13565-905, São Carlos-SP, Brazil.

E-mail: doris@power.ufscar.br 